DOI https://doi.org/10.36059/978-966-397-190-2/46-73

\title{
THE CHRISTIAN PEACEBUILDING PHILOSOPHY
}

\section{Nikolay Nesprava}

\section{INTRODUCTION}

At the beginning of the XXI century, mankind faces with new topical threats. Whereas, in the second half of previous century the study of security concerns revolved around a nuclear confrontation in a bipolar world, where peace was provided by a "balance of fear", now the complex problems of terrorism, separatism, hybrid wars, information warfare, and cyber-attacks are on the agenda. And conflict that destabilizes Ukraine and has led to thousands of victims is especially painful for us. So, peacebuilding is the challenge of our age and urgent task for our country.

We have entered an era of conflict that is taking new forms, and spreading in ways that are outstripping the power of the international community to respond. The dramatic changes taking place in the world are forcing scholars to rethink the secular approaches to considering the age-old dilemma of war and peace that have dominated international relations theory for more than two centuries, and to return the gaze to those spiritual primary sources of understanding ontological, anthropological, and axiological dimensions that are contained in the Christian doctrine. To understand the difference in opponents' approaches, we should refer to an illustration of the antithesis between them, which Professor of Government at Harvard University R. R. Tuck gives an example:

Rhetoricians by their trade were commited to taking the interests of their city as the starting point of their arguents, for they were appealing to political bodies whose raison d'être was the welfare of their particular community. Philosophers were equally committed to a wider view, and to addressing people to non-political context, as were their Christian successors ${ }^{1}$.

The great philosophers have been thinking about the causes of war and ways to achieve eternal peace from ancient times. The synthesis of these considerations led to the formation of a special direction of philosophy, called "philosophy of peace". "In the philosophy of peace, - A. Capto points out, - peace is understood as a concerted relationship, quietude, and absence of hostility, war and quarrels"2.

\footnotetext{
${ }^{1}$ Tuck R. (1999). The Right of War and Peace: Political Thought and the International Order from Grotius to Kant. New York: Oxford University Press, p. 227.

${ }^{2}$ Kapto A. S. (1990). Filosofiya mira: istoki, tendentsii, perspektivyi [The Philosophy of Peace: Sources, Trends, Prospects]. Moscow: Politizdat, p. 12. (in Russian).
} 
This interpretation reflects the essence of peace in the wide social sense. Respectively, experts of Alliance for Peacebuilding note:

Peacebuilding is ultimately an elastic concept, encompassing a wide range of efforts by diverse actors in government and civil society at the community, national, and international levels, to address the immediate impacts and root causes of conflict before, during, and after violent conflict occurs. Peacebuilding ultimately supports human security - providing freedom from fear, freedom from want, and freedom from humiliation ${ }^{3}$.

In a narrow practical sense, peacebuilding is understood as activity that aims to resolve injustice without resorting to deadly violence and to transform the cultural and structural conditions that generate deadly or destructive conflict. And in a broad philosophical sense, peacebuilding is understood as measures to eradicate the causes of potential conflicts between social actors and maintain a sustainable peace.

In this chapter the peacebuilding is considered precisely in this broad philosophical sense. At the same time, the study of Christian peacebuilding philosophy, focusing on the idea of peace as a promising goal, aims to formulate the problem that we must solve in Ukraine in the near future.

\section{The main peace studies' concepts: why state power, economic benefit and international law do not build peace sustainably}

Sustainable peace proposals include many different aspects. Generally, main directions of peacebuilding theory can be grouped into military-political, socio-economic, international legal and spiritual-ethical concepts. In the process of developing knowledge about the peace, scholars have given priority to one or another area of scientific analysis of the problem.

The military-political recipes of ensuring peace by striking a balance of power go back to Thucydides, and through Machiavelli's political doctrine, are reflected in the paradigm of realism and neo-realism, that had reached its apogee during the Cold War as a "balance of fear" strategy. But even the most powerful nuclear arsenals could not save the Soviet Union from its decay. It was overwhelmed by the crisis of spirituality, that was reflected in the politics of double and sometimes triple moral standards. However, the so-called "real politik" concept has many supporters, both among politicians and scholars up to now. For example, Russian social philosopher V. Ksenofontov believes that political content, determined primarily by the dominant economic, political and military elite of states, is crucial necessary to understand the essence of

3 What is Peacebuilding? (2018). Alliance for Peacebuilding. Retrieved from: https://allianceforpeacebuilding.org/what-is-peacebuilding/ (accessed 10 January 2020). 
peace ${ }^{4}$. Similarly, Trump and Putin speak out recently. But such a etatistical approach, that is characteristic of realism, does not reflect the complex picture of modern world. In this world, the role of states is blurred, and the threat of war between states or blocs has been replaced by terrorist explosions, separatism, hybrid and information wars and cyberattacks, and its sources lie hidden in the gray areas of non-state structures. Ukrainian political scientist A. Kostyrev argues, that "in a network society, a hierarchical state power based on the legitimate use of violence is inferior to a communication power formed by horizontal ties between actors who share common spiritual values" ${ }^{\prime 5}$. Since, the confrontation in modern conflicts shifts into the spiritual and informational sphere, so much so, in the process of peacebuilding, the militarians and politicians must give priority to the "catchers of men", as Christ called the apostles (Matt. IV, 18-23).

The origins of socio-economic concept of peace can be found in the writings of Aristotle, but it is most emphasized in the theories of Marxism and neo-Marxism. In the scope of this concept in 1964, J. Galtung developed the theory of "positive peace", that is widely accepted now. In this theory, peace is not just the absence of war, peace must include freedom from hunger and oppression, but also serve its purposes - economic development and social justice. Following this logic, the developers of "cooperative peace" theory argue that in an era of economic globalization, the peace must globalize also. But there are several counterarguments to the apologists of this theory. First, in accordance with I. Wallerstein's theory, the gap between the "core" countries, its population is called the "golden billion", and the poorer "periphery" countries is steadily increasing. Secondly, the facts indicate that economic and cultural globalization really means westernisation and unification, that caused a reaction in the form of aggressive nationalism and jihad. Third, even close economic relationships are not guarantee against intrusion by "partners". It has happened in Libya, Syria and, unfortunately, in Ukraine.

Consequently, contrary to F. Fukuyama's predictions, the Western model of combining a market economy with liberal democracy could not become a universal recipe for peace. The reason of this statement is discovered in the fact that, without a religious and ethical basis, the natural right to consumption transforms the society from a moral and spiritual formation into a secularized "society of consumption", and its crisis we have observed since 2008. It is

\footnotetext{
${ }^{4}$ Ksenofontov V. N. (2008). Mir kak sostoyanie obschestva [Peace as a state of society]. Moscow: Russian Academy of Public Administration, p. 42. (in Russian).

5 Kostyrev A. (2013). Kommunikatsionnaya vlast: sotsialnyie seti kak instrumentyi noopolitiki [Communication power: social networks as tools of noopolitics]. Political design in the space of social communications, vol. 2, p. 54. (in Russian).
} 
impossible to achieve harmony in market relations without the self-restraint that results from religious education. Therefore, international market turns into series of conflicts with increasing tension.

Although international treaties have been known as a peace agreement since the time of Hammurabi, the international legal concept of peace originates from G. Grotius. In his treatise "On the Law of War and Peace", the Dutch philosopher suggested ways of sanctioning and deterring war, that would be based on rational principles. Ideally, he saw the international community governed less by Christian authority than by negotiations and treaties between states. The long-known definition of "just war" has found its scientific justification within this theory. But, as British writer J. Gittings points out, "totalitarian regimes demanded its protection just as likely as liberal or democratic governments; and both sides in the Crimean, Boer and two World Wars insisted that their war was just" ${ }^{\text {"6 }}$. It should be emphasized that we have heard a similar argument to justify US intervention in Iraq and Russia's annexation of Crimea. Thus, no wonder that I. Kant claimed that the international law doctrine of just war only provided a fig leaf for aggression. In the same context, we are increasingly seeing a conflict between the fundamental principles of the UN, that were intended to ensure peace on the planet. The double standards in interpreting the principles of the right of indigenous peoples to self-determination and territorial integrity of states, as well as the principles of defence of human rights and sovereignty of states, serve as justifications for aggression. And the practical irresponsibility of the UN Security Council member states is opening their hands. This is a factual confirmation of F. Dostoevsky's opinion that if God is not there then all is permissible. In this case, it is mean that there is no God in the souls of the leaders of the aggressor states and therefore no treaties are an obstacle to them. Obviously, that all endevors to justify the wars of some kind of legal basis are caused by political interests.

Therefore, it is logically justified to pay particular attention to the spiritual-ethical concept of peace, sometimes called idealistic. Philosophers, who develop this concept, focus on the ethical aspects of peace and believe that the moral re-education of people in the spirit of humanism is capable to achieve a sustainable universal peace. American philosopher W. Hamblet notes, that discussion between apologists of realistic and idealistic theories has begun from Socrates' dispute with the disciples over the question of justice in human societies by establishing a model of the battle between power and

${ }^{6}$ Gittings J. (2015). Philosophy and Peace. The Question of Peace in Modern Political Thought, ed. by T. Koivukoski \& D. E. Tabachnick. Waterloo: Wilfred Laurier University Press, p. 36 . 
persuasion ${ }^{7}$. But Christian peacebuilding philosophy looks on this problem much more wider and deeper.

\section{Ontological, Anthropological, Axiological and Praxeological Measurements of Christian peacebuilding philosophy}

The ideas of peacebuilding are an integral part of the worldview systems of ancient philosophy, Confucianism, Hinduism and Buddhism. But the origins of the spiritual and ethical concept of peace must be found in the Bible narratives, which formed the basis for the formation of ontological and axiological approaches to peacebuilding in Judaism, Christianity and Islam. The Priestly Blessing ends with significant words: "May God lift up his face onto you and give you peace" (Numbers 6:2426).

It is important to pay attention that Christian philosophy represents the peace at the same time as a basic category of being and as an all-embracing complex value. As the great Christian humanist Desiderius Erasmus said, "peace is the mother and nanny of all the good that humanity has" ${ }^{8}$. Without peace, all other human aspirations lose their meaning, "because if there is everything that is valued in this world, wealth, health, wife, children, home, family ... but there will be no good - peace, what is the use of all blessings, pleasure which will stop the war?"9 Therefore, peacebuilding determines the whole meaning of human being, for with peace "the fruits of the Spirit appear: love, joy, goodness, longsuffering, and all the benefits of the Apostle" (Gal. 5:22).

\subsection{Human Life and Dignity: for What Peace is Build}

The right to life is the ontological basis of peacebuilding. The secular statement in this regard is quite simple: the individual's right to life is conditioned only by the fact that he is a human. But it is noticeable that this formula lacks the evidence base. After all, the human right to life is not conditioned by its biological nature, because it is clear to everyone that it is fundamentally different from the rights of animals and other environmental objects that "green" stand for. A more persuasive approach is based on the Biblical conception of man as God's creation. The essensial peacebuilding

\footnotetext{
${ }^{7}$ Hamblet W. (2017). Harvesting the Human: Force and Persuasion in Human Societies. Concerned Philosophers for Peace Newsletter Online. Retrieved from: http://peacephilosophy.org/325/wendy-hamblet-harvesting-the-human-force-and-persuasion-inhuman-societies (accessed 12 January 2020).

${ }^{8}$ Quoted by Gittings J. (2015). Philosophy and Peace. The Question of Peace in Modern Political Thought, p. 28.

${ }^{9}$ Gregory of Nyssa, st. (1863). O blazhenstvakh. Slovo 7 [About bliss. Word 7]. Complete set of Works. Mosow: V. Gotie's typography. P. 455. (in Russian).
} 
principle is based on this approach exactly, it was proclaimed in the sixth commandment of the law of God: "Thou shalt not kill!", which was communicated to men by Moses 3.5 thousand years ago. As Russian lawyer P. Barenboim points out, "for the sake of completeness to understand the meaning of this commandment, it should be added that, according to the prophets, one who wishes to die to another person, who does not help the poor and sick, who does not live with others in harmony and in peace, and, on the contrary, treats others with hatred, envy and malice, engulfs with others quarrels and fights, offends others. All the wicked and the strong who offend the weak are sinning against the sixth commandment" ${ }^{\prime 10}$.

Practically all religious teachings proceed from this principle. However, only in Christianity human life is an absolute value. Christianity, unlike other Avramist religions, considers a person not only as a unique creation of God, created by Him in His own image and likeness, but also as a creature, in which God embodied one of his hypostases in the image of Christ, that is, became humanized. Christianity argues that God not only created human, but also became a man in the image of the Savior, without dissolving man in Himself. Having taken upon himself human sins, the Savior opened before everyone not only the prospect of eternal life, but also pointed out the possibility of atonement for sins through repentance already in this earthly life. Sincere repentance in the face of the Lord, according to Christian doctrine, can lead even an inveterate sinner to the path of the true and will be granted Salvation. American religious scholar R. Traer notes that "the right to life, which is respected as the first of natural rights, essentially emerges from the value, which God gives for the life of human by one's creation and salvation" $"$.

Therefore, in accordance with the Christian dogma, any murder, no matter what motives people use to try to justify it, is a violation of the Higher Purpose of returning a human to God. And since the violation of God's commandment is evil, therefore, any murder is evil, and because a war is a massacre, it is a thousandfold evil, which cannot be justified. Attention should be paid to the fact how much Christian axiology and teleology differ from pagan and even Muslim ideologies in this respect. Paganism and Islam actively promote military prowess as a priority value and motivate their believers to military exploits,

${ }^{10}$ Barenboym P. D. (2016). Bybleyskiy moment philosophiyi prava [Biblical moment of the philosophy of law]. Mediaglagol. Pravoslavnyi obrazovatel'nyi portal [Mediaglagol. Ortodox educational portal]. (in Russian). Retrieved from: http://mediaglagol.com.ua/book/bibleyiskiyi_ moment_filosofii_prava_pd_barenboyim. (accessed 15 January 2020).

11 Traer R. (2009). Christian Support for Human Rights. Religion and Human Rights. Retrieved from: http://religionhumanrights.com/Religion/Christian/christian.fhr.htm (accessed 14 January 2020). 
promising eternal bliss in the Valhalla to perished Vikings, and guaranteeing the status of holy martyrs and a place in paradise, where gurians will appease them, for shahids. It is true that in the Middle Ages the Popes also tried to manipulate the feelings of believers and promised the forgiveness of sins to crusaders, opening them the way to the salvation. But in general, Christianity as a spiritual system does not motivate people to war, but to peacebuilding. For in fact, Christ did not promise bliss to warriors. On the contrary, He equated the peacemakers with the sons of God, proclaiming: "Blessed are the peacemakers, for they will be called the sons of God" (Matt. 5:9).

Christian Churches proceed from the premise that greater co-operation in the field of conflict resolution, including in the Donbas, must be an universal recognition of the high value of the human personality, and an understanding that any war threatens to destroy God's creation and life. The All-Ukrainian Council of Churches and Religious Organizations have proclaimed:

When the lives and health of some people become instruments by which others seek to gain certain political preferences and benefits, it will not only diminish the value of the lives of the hostages and captives themselves, but it is a challenge to the rights and freedoms of the whole world, because the pain and humiliation of any human being is the tragedy of all mankind ${ }^{12}$.

The problem has become even more complicated in connection with the development and using of hybrid warfare methods, one of the main elements of which is the manipulation of public opinion and the substitution of values. For the solution of this problem at the ideological level scholars should refer to the concept of human dignity.

Human dignity as a spiritual basis of peacebuilding philosophy logically derives from the faith in Christ the Savior. As the Dutch researcher of human rights and jurisprudence B. Fortman proclaims, "Christ - God and man - is the deepest source and guarantee for the dignity of the human person"13. However, Christian axiology of human rights distinguishes the value of life from the value of human dignity. Life is given by God, and dignity is acquired by human. The person becomes dignified by doing goodness.

In order to understand the significance of this category for the philosophy of peacebuilding, it is important to emphasize that in the Christian tradition

12 Zvernennya Vseukrayins'koyi Rady' Cerkov i Religijny'h Organizacij shhodo stanovlennya spravedly'vosti v Ukrayini [The Statement of the All-Ukrainian Council of Churches and Religious Organizations on the establishment of justice in Ukraine]. Kyiv, 17 May 2016. (in Ukrainian). Retrieved from: http://vrciro.org.ua/ua/statements/465-uccrostatementjustice-court-judge-ukraine (accessed 16 January 2020).

${ }^{13}$ Fortman B. (2011) Religion and Human Rights: A Dialectical Relationship. e-International Relations. 05 Dec. Retrieved from: http://www.e-ir.info/2011/12/05/religion-and-human-rights-adialectical-relationship/ (accessed 14 January 2020). 
the concept of "dignity" has primarily a moral meaning, and a notion what is worthy, and what is not worthy is closely related to the moral or immoral actions of a person and to his or her internal soul's state. An individual acquires dignity in the pursuit of good. On the contrary, when an individual chooses evil, freedom of choice leads him or her to self-destruction and damages a human dignity and public peace. Immutable and non-manipulated principles of good are given to human in Gospel commandments. As the great Christian saints pointed out, "the one who creates the peace, creates it through the transformation of evil, that is, through the change and bringing of evil for the better" ${ }^{\prime 4}$. Recall that, according to the theologians, the fight against evil is the highest purpose of human, and then the commandment, according to which the Lord calls the peacemaker the son of God, will be better understood. The one of the Great Christian Teachers - Gregory of Nyssa emphasized:

To the one who prevented the calamity of war the Lord gives two gifts at once: one is the reward by which he becomes a successor of God, and the other is the feat, because if for such a thing and nothing it was necessary to have in hope, then peace in itself for those who has a mind, is more expensive than any care about it ${ }^{15}$.

But Christian Teachers have pointed out that peacebuilding requires not only hard spiritual work for the sake of good to achieve one's dignity, but also for such moral behavior that does not affect the dignity of another person. Human cannot show one's dignity by humiliating another person. This leads to the first formulation of the categorical imperative, sometimes called the "universalizability principle": "Act only according to that maxim whereby you can at the same time will that it should become a universal law"16. In fact, this imperative is the philosophical formalized commandment of Christ, who proclaimed in the Sermon on the Mount: "Therefore, whatever you want others to do for you, do also the same for them, for this is the Law and the Prophets" (Matt. 7:12). And it is not accidental, because I. Kant was convinced that moral faith in God, in the Kingdom of God as the highest good, in personal immortality is not based on hypotheses and imaginary evidence of theoretical reason, but it is based on an unconditionally true conclusion, which is drawn from the nature of morality and human nature as a moral being. While liberal theories absolutize the dignity of the individual, Christian interpretation points to its relational nature. Primordial dignity,

\footnotetext{
${ }^{14}$ Basil the Great, st. (2008). Beseda 9. O tom, chto Bog nie vinovnik zla [Conversation 9, That God is not the culprit of evil. Works, Vol. 1. Moscow: Blagovest. P. 356. (in Russian).

${ }^{15}$ Gregory of Nyssa, st. (1863). O blazhenstvah. Slovo 7 [About bliss. Word 7]. P. 458.

${ }^{16}$ Kant I. (1993). Grounding for the Metaphysics of Morals. Trans. by J. W. Ellington, ( $3^{\text {rd }}$ ed.). Indianoapolis: Hackett. P. 30.
} 
conditioned by the creation of human in the image and likeness of God, is not a fixed constant. The social essence of human demands to constantly nurture this virtue, making conscious free choice for the benefit of good towards others and an environment. The Christian conception of peacebuilding formulates the human dignity as a priority of duties towards his neighbors in compare with their own rights. Apostle Paul proclaimed: "Let nobody seek his own, but each one [benefits] of another ... for what would my will be judged by another's conscience?" (1 Corinth. 10: 23-24, 29). Kant relied on Christian postulates and emphasizes that duty is the highest form of moral behavior.

The problem is how human dignity, as a personal pursuit of good, relates to the dominant social views. A history is full of examples when those who sought reconciliation were accused as traitors, and those who sought war were celebrated as heroes. And the dramatic Ukrainian realities oblige us to recollect Ecclesiastes' direction: "The quiet words of the wise are more to be heeded than the shouts of a ruler of fools. Wisdom is better than weapons of war, but one sinner destroys much good" (Ecclesiastes 9:17-18). Great Christian peacemaker and humanist Pope John Paul II accented on the problem of human dignity's relativity:

A human receives from God his essential dignity and, with it, the ability to exalted himself above any social order in search of truth and goodness, however, it is due by the social structure in which he lives, also by the education and the environment ${ }^{17}$.

And so, human must again and again comprehend the difficult art of earthly human co-existence as a ministry, purpose and duty. In this context, attention should be paid to the fact that such a basic value of the peacebuilding philosophy as justice flows logically from the Christian understanding of human dignity as a moral obligation to God and people. And B. Fortman states: "Unquestionably then, the fellowship that human beings are called upon to establish is not just a matter of envisioning the others as free and equal creatures but also of doing justice and living together in peace"18.

\subsection{Justice as Love and Charity: by What Peace is Build}

The Christian worldview platform has enabled thinkers to identify the teleology of justice. According to Thomas Aquinas, the goal of justice is to guide our actions in accordance with the common good. Exactly this goal focuses all peacebuilding efforts. In doing so, the praxeological aspects of this

${ }^{17}$ John Paul II (1991) Encyclical Centesimus annus. Ukrainian Catholic University: Institute of Religion and Society. (in Ukrainian). Retrieved from: http://irs.ucu.edu.ua/dzherela/sotsialnientsikliki/ivan-pavlo-ii-centesimus-annus-1991. (accessed 20 January 2020).

${ }^{18}$ Fortman B. (2011) Religion and Human Rights: A Dialectical Relationship. 
activity are revealed through Christian ethical principles. F. Bacon, the founder of modern philosophy, in fact returning to the Gospel guidelines, stated that "justice is not to do to others what you do not wish for yourself". In an extramural dispute with Machiavelli and Hobbes, he made the conclusion of the peacebuilding philosophy that "it is only through the presence of justice a human is a god, not a wolf for others" ${ }^{\prime 19}$. In the context of our study, it will be interesting to note that this scholar, who is considered an opponent of scholasticism and an apologist for empiricism, insisted that "superficial philosophy inclines the mind of human to godlessness; the depths of philosophy turn human's minds to religion" ${ }^{20}$. Kant believed that justice is the basis and purpose of human life. He argued that "if justice disappears, life on earth will no longer have any value" 21 .

It should be noted that in the Christian peacebuilding philosophy justice as an axiological category acquires a deep ontological content. Christian philosophy gives an interpretation of justice as a human's reflection of the supreme God's law. Traer emphasizes that "Christians assert that because God loves all people, all people have rights and the corresponding duties to respect the rights of all others" ${ }^{, 2}$. In order to understand the peacebuilding essence of the Christian ontology of justice, it is important to note that, although its roots extend back to the Old Testament, Christian approaches to justice are fundamentally different from the laws of Moses. The Old Testament contains one of the oldest known formulations of the talion principle - the phrase "eye for eye, tooth for tooth" was quoted from Exodus (21: 23-27), and also was repeated in Leviticus (24:20), which not only justifies violence but commits to it actually. This principle underlies the tradition of blood revenge exactly. However, a revenge has not a measure, one revenge generates another, another - a third, which can lead to the complete destruction of the genus. That is, after all, that an evil will win and a death will dominate.

But in Christ, who "death trampled upon death", humanity has found a chance for salvation. The charity professed by Christianity is related to the principle of equal repayment, according to the dialectical law of "denial of denial". In the Sermon on the Mount, Christ proclaimed: "You have heard that our parents were told: 'Eye for eye, and tooth for tooth'. But I tell you, don't resist an evildoer. On the contrary, if anyone slaps you on your right cheek,

${ }^{19}$ Bacon F. (2014). Introductory dedication of "An Advertisement Touching a Holy War" to Bishop Lancelot Andrews. The Essays and Counsels, Civil and Morales. B\&R Samizdat Express. P. 356.

${ }^{20}$ Bacon F. (2014). Of Atheism. The Essays and Counsels, Civil and Morales. B\&R Samizdat Express. p. 231.

${ }^{21}$ Kant I. (1993). Grounding for the Metaphysics of Morals. P. 265.

22 Traer R. (2015). Christian Support for Human Rights. 
turn the other to him also" (Mtt. 5: 38-41). As applied to peacebuilding, it is perhaps one of the Savior's most paradoxical teachings. Does it mean indulging the evil of violence actually? Not at all! The point is that the peacemaker must suppress the bitterness in himself and find the strength to forgive the offender. Thus, Christian justice means the victory of good over evil essentially. The Apostle Paul explains what his Teacher said precisely: "Do not be overcome by evil, but overcome evil with good" (Rom. 12:21). That is why forgiveness and charity have become distinctive markers of the Christian peacebuilding philosophy.

They help to find a way out of the stalemate known in politics as the syndrome "Our boys died not in vain". This syndrome manifests itself in Ukraine. But now in our country it is so painful that it is better to turn to the example that the Israeli historian and philosopher Y. N. Harari describes. In 1915, Italy entered the First World War on the side of the Entente. State proclaimed as its goal the "liberation" of Trento and Trieste "unjustly" held by Austria-Hungary. Italian politicians shook the air with fiery speeches. Hundreds of thousands of Italian volunteers rushed to the front with shouts: "For Trento and Trieste!" They thought it would be a walk. A glorious adventure turned into a bloody massacre. But it was difficult for politicians to tell parents that their son had died in vain, and it was even more difficult for father and mother to say this to themselves. After all, if the Italian national myth was a lie, then they have to admit that the death of their son is absolutely meaningless. Few people can do it. Therefore, politicians sent soldiers into a second attack and laid down thousands more. And then they again chose the continuation of the war - because "our boys died not in vain". By the end of the war, nearly 700 thousand Italian soldiers were killed and more than half a million were injured, but Italy never received the territories it claimed ${ }^{23}$. Obviously, it was enough to recall the Gospel commandments about the pricelessness of human life in order to avoid the outbreak of war. And if politicians made a criminal mistake, and the war nevertheless began, then people should promptly and unconditionally accept the Christian principle of forgiveness to the leadership in order to stop the snowball of bloody victims. We must to draw relevant historical parallels and to conclude that our boys did not die in vain - they taught us a harsh lesson that must never be forgotten - a violating the Savior's commandments is evil for which reckoning follows.

There is no doubt that philanthropy is a distinctive feature of Christianity. In the Gospel, we find not only a clear commandment: "Love your neighbor

${ }^{23}$ Harari Y. N. (2016). Homo Deus: A Brief History of Tomorrow. London: Harvill Secker. Pp. 351-353. 
as yourself" (Matt. 22:39), but also a more complicated cognitive model: "Love your enemies, bless those who curse you, who hate you, and pray for those who offend you and lead you, so that you may be the sons of your Father in heaven" (Mat. 5: 43-46). It is useful to address to the conclusions of P. Yurkevich, the founder of the "philosophy of a heart", to understand the peacebuilding potential of the Christian awareness of justice. This Ukrainian thinker argued:

With the highest moral development, a person obeys the commandments of love, which inspires him to sacrifice his personal benefits for the benefit of others, for the benefit of the common. In justice and love are the most durable conditions for peace among people, for the foundation of common friendship and brotherhood between them. And so those who awaken in a human these moral requirements are peacebuilders essentially ${ }^{24}$.

It is important to note that it is through the notion of love that Great Christian Teachers revealed the meaning of the concept of "peace". In their opinion, the opposite of love is hatred, anger, irritation, envy, malice, hypocrisy, disaster of $\operatorname{war}^{25}$. In general, the philosophy of peace, and even wider - the whole social philosophy, in its Christian interpretation is a philosophy of love essentially. This clearly demonstrates the statement of the Russian thinker S. Frank:

The great moral principle: "love your neighbor as yourself", even if in a weakened, diminished form of simple discretion in another person "neighbor", "like yourself", perceiving him as "you", i.e. as a creature, which connected with me and identical with "me", with whose fate my fate is connected - there is an unshakable and eternal foundation, without that society is unthinkable; and all sorts of newest "individualism", no matter what it preaches and no matter how much relative truth it contains, cannot violate or annul this first and fundamental principle of the public ${ }^{26}$.

Thus, Christian philosophers argue that love is the anthropological essence of peacebuilding, because it restrains the "natural" envy and hatred of

${ }^{24}$ Yurkevich P. D. (1860). Mir s blizhnim kak usloviye khristianskogo obshchyezhytiya (Trudy Kyivskoy Duhovnoy Academiyi) [Peace with the neighbor as a condition of a Christian cohabitation (The Works of the Kyiv Theological Academy)]. Philosophskiye proizvyedyeniya [The Philosophical Works]. Moscow: Znaniye, 1990. P. 74. (in Russian).

${ }^{25}$ Gregory the Theologian, st. (1912). Slovo 6, O mirie, skzannoie v prisutstvii ottza poslie priedydushchiego molchaniia po sluchaiu vossoiedinieniia monahov [Word 6, About the Peace, was said in the presence of the father after the previous silence, on the occasion of the reunion of monks]. Tvoreniya izhe vo svyatykh ottsa nashego Grigoriya Bogoslova, Arkhiepiskopa Konstantinopolskogo [The Works of Our Holy Father Gregory the Theologian, Archbishop of Constantinople]. vol. 1. Sankt-Peterburg: Petr Soykin Publ. (in Russian).

${ }^{26}$ Frank S. L. (1925). Religioznyie osnovy obshchestvennosti [Religious Foundations of the Public]. Put' [The Way], no. 1, pp. 12-13. (in Russian). 
individuals, on which pointed the attention Machiavelli and Hobbes and their successors from the 'political realists' camp. If force-based order in any case leads to conflict and disintegration of the constituent parts ultimately, and formal social treaty can't preserve the unity of warring individuals for a long time, then love, accompanied by forgiveness and repentance, is capable to unite even an offender and his victim. This approach paves the way not only for establishing harmony in society, but also for peaceful coexistence between states. It also provides guidelines for solving the complex international law dilemma of the relation between state sovereignty and a need for peace on the planet. As Tuck stresses:

Kant's intention was to show: it was not the case that one was caught between the Scylla of a world state and Charybdis of perpetual war. The central aspect of this claim was that the rules governing the relationship of modern states would be minimal in character, thinker (on Kant's account) that Hobbesian state of nature, but much thinner than those of a civil society ${ }^{27}$.

Christian definition of justice as ontological and axiological core of social relations is a distinctive feature of peacebuilding principles that interpret justice in terms of equality and solidarity. Thomas Aquinas, commenting the content of the assessment of social relations based on the criterion of justice, pointed out that an act is "just", if it is coordinated with another person by means of some equality ${ }^{28}$. In a special way, Christian humanity and solidarity are expressed in the words of St. Paul: "Does one member suffer, all members suffer from it? and when one member rejoices, all members rejoice with him" (Rom. 3: 37-38). Christian tradition requires not only to build the peace on a moral basis, but also through alms-deed, following the teachings of Apostle Paul: "By working, we must support the weak and remember the words of the Lord Jesus, for He Himself said: "It is more blessed to give than to take" (Acts 20:35). So, solidarity and subsidiarity are the fundamental principles of Christian peacebuilding philosophy.

Another fundamental principle of Christian peacebuilding philosophy non-discrimination - comes from moral values too. On this subject, the Christian tradition has a clear position. Christians believe that "God from the same blood has formed the whole human race for living all over the face of the earth" (Acts 17:26) and that in Christ "there is no Jew or Greek, there is no slave, nor free, no man, nor woman because you are all one in Christ Jesus"

27 Tuck R. (1999). The Right of War and Peace: Political Thought and the International Order from Grotius to Kant. P. 221.

${ }^{28}$ Thomas Aquinas, st. (2010). O spravedlivosti, vopros 91. Summa teologiyi [About a Justice, question 58. Summa Theologiae]: in 12 vol. Ed. by S. I. Yeremeyev. Kyiv: Nika-Centre, vol. VI. (in Russian). Retrieved from: https://azbyka.ru/otechnik/konfessii/summa-teologii-tom-6/ (accessed 19 January 2020). 
(Gal. 3:28). This fruitful source has to continue to nourish the value content of the human rights concept that is the bar of international peacebuilding system. Although in the Middle Ages the Church spread the demand to preserve peace only to Christian world and consecrated the crusades against the unbelievers as a divine deed, but even then the leading theologians defended the idea of peace as a universal value.

However, it should be noted that the problem of identity has been and remains one of the key issues in the peacebuilding. And Renaissance jurist and humanist Andrea Alciato's statement testifies to this:

When war is declared against Turks and Saracens, there are the rights of postliminium, and those taken in war become the property of the captors, but in is otherwise among Christians, for under the law of CHRIST all men are brothers, so that war between them is even worse than civil war; so there is no right of postliminium in this case ${ }^{29}$.

The events of the XXI century confirm that medieval religious intolerance and marginal ethno-nationalism, born in the XIX century, having experienced both fascism and communism, remain the main stimulators of conflict and are used by paranoid politicians to incite hatred and wars in a according to the well-known Rome empire's formula "divide et impera". However, Bible teaching provides the advice in this case: "They will beat their swords into plowshares and their spears into pruning hooks. Nation will not take up sword against nation, nor will they train for war anymore" (Isaiah 2:4; Micah 4:3). And it is necessary to accent that "the LORD examines the righteous, but the wicked, those who love violence, he hates with a passion" (Psalms 11:5).

\subsection{The Power for Peace: a Sword in the Saint's Hands}

In general, the problem of using violence against violence, also known as "the power for peace", is one of the most difficult in peace studies. Norwegian sociologis and founder of the discipline of peace and conflict studies J. Galtung distinguishes: a) a direct, or "hot" violence, which refers to acts that impose immediate harm on a given subject or group; b) a structural violence, which refers to the ways that systems and institutions in society cause, reinforce, or perpetuate direct violence; c) a cultural violence, which refers to aspects of culture that can be used to justify or legitimize direct or structural violence - the ways in which direct or structural violence look or feel "right" according to the moral fabric of society ${ }^{30}$. The measures which are provided in the plans of "negative peace", then - "positive peace" and

\footnotetext{
${ }^{29}$ Tuck R. (1999). The Right of War and Peace: Political Thought and the International Order from Grotius to Kant. P. 28.

${ }^{30}$ Galtung J. (1990). Cultural Violence. Journal of Peace Research, vol. 27, iss. 3, pp. 291-305. doi:10.1177/0022343390027003005.
} 
finally - "justpeace" (or "just peace") are used to curb the manifestation of these types of violence successively ${ }^{31}$. But from the standpoint of understanding the peacebuilding in a broad philosophical sense, the problem of the possibility of using violence to prevent conflict or to establish peace remains open. In the Old Testament violence is viewed not only as evil, but also as a necessary punishment for sin or just vengeance. On the contrary, the Christian ontological and axiological paradigm, recognizing the permissibility of violence to deal with the concrete manifestations of sinful evil in certain cases, proclaims non-violence as a moral obligation arising from Gospel commandments.

The Christian principles of nonviolence have found the most uncompromising expression in the L. N. Tolstoy's doctrine of non-resistance to evil by violence, in which he views evil as some chain reaction. Once occurring, evil engenders appropriate actions which, even if justified, are generally not contained within the framework of justice, it gives a rise to new evil, and on an even larger scale than before. Great Russian writer concludes that the determination to refrain from retribution for the harm done, including from the right to self-defense, is the only way to stop this devastating process. The main thing, in Tolstoy's opinion, lies not in the act of renouncing revenge, but in the clarified sense of love for all without exception, that moves the morally educated person. From the point of view of evaluating the practical application of this concept, American theologian and peacemaking researcher $\mathrm{T}$. Rynne recommends to refer to the political experience of Mahatma Gandhi, who adopted the concept of nonviolence found in the New Testament, in particular in the Sermon on the Mount, and made extensive use of social and political struggles in his strategy ${ }^{32}$. In modern philosophy of peace, this peace-making teaching of Christ has become the most complete form in the ideology of pacifism, which is justified by the belief in the moral unacceptability of war in principle. At the same time, in pacifism, spiritual and ethical guidelines are considered as the basis of the triad - scientific study of the problems of peace, education in the spirit of peace, and actions for the realization of peace (peacekeeping and peacebuilding).

It should be noted that opponents cast doubt on the allegations of pacifists about the onset of sustainable peace as a result of the perceived refusal of people, political structures and states from all forms of violence. The apologists of political realism are skeptical to the peacebuilding potential of the religious Renaissance, the spiritual perfection of humanity, the humanistic

\footnotetext{
${ }^{31}$ Galtung J. (2011). Peace, Positive and Negative. The Encyclopedia of Peace Psychology, American Cancer Society, pp. 23-54. doi:10.1002/9780470672532.

${ }^{32}$ Rynne T. J. (2008). Gandhi and Jesus: The Saving Power of Nonviolence. London: Orbis Books, p. 54-55.
} 
activity of state, public, and religious leaders ${ }^{33}$. But adherents of the spiritualethical concept point to the dialectical nature of the fight against the terror of war and the hope of an "era of charity". St. Augustine though convinced that it was more glory to end the war with one word than to kill people with the sword, but at the same time wrote:

Christian could use violence on behalf of his city as long as it was clearly recognized that it was deeply unfortunate duty brought about by a clear case of injustice in the world, and that violence was intended to protect those things in accordance with law by which peace and human society are preserved on the basis of such things ${ }^{34}$.

The Christian peacebuilding philosophy proposes its ontological and anthropological view of conflict nature as the starting point in solving the problem of violence. Christians believe that any conflicts are the result of connivance to sinful passions: "What is the source of wars and fights among you? Don't they come from your passions that wage war within you?"(Jas. 4:1). The Sixth Ecumenical Orthodox Council expressly defined sin as a disease of the soul, and conflicts, strife, crimes and wars with their tragic consequences are only external symptoms of this disease. Therefore, as the Church leaders emphasize, not only the external symptoms of this disease but also the disease itself - sin, must be eliminated in order to prevent crimes, ending wars and overcoming terrorism ${ }^{35}$.

As a surgeon uses a scalpel to remove a malignant tumor and can cause pain to the patient, so healing sin may require the use of force and cause suffering. And in this sense the expression of Christ "Don't assume that I came to bring peace on the earth. I did not come to bring peace, but a sword." (Mt 10:34), which is interpreted ambiguously, has to be understood. According to the Gospel, Christian philosophers say with certainty that the lifelong existence of evil does not mean that human should not fight it, moreover, this deed is human's divine purpose. This statement is the ontological basis of teleology of peacebuilding. It follows from the crucial conclusion of the Christian saints that the "not God fights against evil, but human!"36, because God created human for good.

${ }^{33}$ Koshin V. (1990). Filosofiya mira v yadernyiy vek [The philosophy of peace in the nuclear age]. Voprosyi filosofii [The Questions of Philosophy], no. 5, pp. 39-54. (in Russian).

${ }^{34}$ Augustine, st. (1943). Answer to Sceptics. Ed. by R. Arbesman. Trans. D. J. Kavanagh. New York. P. 74.

${ }^{35}$ Missiya Pravoslavnoi Tcerkvi v sovremennom mire [Orthodox Church's mission in the modern world]. VI Vsemirnyi Pravoslavnyi Sobor [VI World Orthodox Meeting], Shambezy, 26-28 Jan. 2016. (in Russian). Retrieved from: http://www.patriarchia.ru/db/print/4360988.html (accessed 18 January 2020).

36 Gregory the Theologian, st. (1912). Chudiesnyie pesnopieniia. Slovo 4, o mirie [The mysterious chants. Word 4, about the Peace. Tvoreniya izhe vo svyatykh ottsa nashego 
So, Christian thinkers argue that there is an essential differentiation between sinful and non-sinful violence. Relying on the position of the Christian ontological and axiological paradigm, we can offer the criteria by which violent actions should be classification as non-sinful accordingly to Christian peacebuilding philosophy. The violence, the genesis of which is ontologically linked to evil, can, however, be defined as non- sinful and have some justification from the standpoint of Christian axiology if: firstly, it has a character of warning or counteraction, and not revenge; secondly, it does not degrade the human dignity; thirdly, and most importantly, it is directed by the higher postulates of love, rather than by the struggle for material values, socio-political or religious ideals.

The Christian peacebuilding philosophy inferences that only victory over evil in one's soul opens the possibility for a person to use force adequately. Such a view, while affirming the rule of love in human relations, strongly rejects the idea of resisting evil by force ${ }^{37}$. Russian philosopher I. Ilyin wrote:

Who resists villains by force and sword must be purer and above his own struggle; otherwise he will not lead it and he will not finish it with victory, but it will seize him, distort his face and throw him away, broken, humiliated and vicious. Only the one who possesses himself, that is, his passions and his vision, can possess the power and the sword ${ }^{38}$.

The dramatic events in Ukraine confirm that real peace in society cannot be achieved without "killing the dragon" first and foremost in oneself. Great Christian teachers also pointed to this thesis in their time, based on the theistic ontology of the good developed by them. Gregory of Nyssa explained the importance of internal peacebuilding as a means of virtue:

Because good is not only what is delivered to others, so we call the peacemaker in the full sense that one who leads the rebellion of the flesh and spirit, and the interpersonal curse of nature in itself to peaceful consent ${ }^{39}$.

Yurkevich revealed in detail the Christian contents of peacebuilding as a human-building:

Grigoriya Bogoslova, Arkhiepiskopa Konstantinopolskogo [The Works of Our Holy Father Gregory the Theologian, Archbishop of Constantinople]. vol. 1. Sankt-Peterburg: Petr Soykin Publ. P. 25. (in Russian).

${ }^{37}$ Osnovy sotcialnoyi kontceptciyi Rus'koyi Pravoslavnoyi Tcerkvy [The Fundamentals of the Russian Orthodox Church's Social Concept] (2002). Kyiv: Information and Publishing Center of the Ukrainian Orthodox Church. (in Ukranian). Retrieved from http://www.patriarchia.ru/ua/ db/text/1207692.html (accessed 16 January 2020).

${ }^{38}$ Ilyin I. A. (1995). O soprotivlenii zlu siloiu [About resistance to evil by force]. Collected Works in 10 vol. Vol. 5. Moscow: Russkaia kniga. P. 217. (in Russian).

${ }^{39}$ Gregory of Nyssa, st. (1863). O blazhenstvah. Slovo 7 [About bliss. Word 7]. P. 466. (in Russian). 
In general, peace with people requires, as a necessary condition, that a person has to be in peace with himself, or that he has an inner peace of mind that is achieved by self-control, triumph over passions, obedience to the voice of conscience, and especially active devotion to the will of $\operatorname{God}^{40}$.

Thus, a peacebuilding is presented in Christian philosophy as the way to inner unity - to good. But it should be emphasized that in the interpretations of Christian thinkers, these efforts are represented as having not only ethical but also ontological content, because inner unity as deliverance from the temptation of evil and reunion with God, is a deification that opens the way of return to paradise.

While apologists of 'real politik' see the use or threat of violence as the only means of securing peace, and unable to see the long-term harmful effects of the principle si vis pacem - para bellum, supporters of a spiritual and ethical concept direct their peacekeeping efforts to eradicate true causes of wars and terrorism. The challenge is to act peacefully in a world where the principle of "peace through force" is used to resolve conflicts, and where "force" is mistaken for violence ${ }^{41}$ Christ gave the recipe of such actions in his time, when he escaped violence against a woman caught in adultery, which seemed legitimate but contradicted the spirit of mercy, with one phrase: "Let any one of you who is without $\sin$ be the first to throw a stone at her" (John 8:7).

Therefore, according to Christian moral philosophy, the sword can only be valid in the saint's hands. But since the height of the righteous can be attained only by individual spiritual cultivation, so group righteousness does not occur. Such claims of some social groups, parties, ethnos, or states have inevitably led to tragic consequences. But even now, people hear claims of "exclusivity" or "special mission" from the mouths of some "great nations" leaders. Thus, since group righteousness does not exist, and war or revolution is always a mass violence, so in the Christian philosophical spiritual sense a just violent social conflict is impossible. From a truly Christian point of view, not clouded by political interests, "holy war" and "revolution of dignity" are purely propaganda definitions that are devoid of moral content.

But at the same time, Christian philosophers have introduced a clear differentiation of responsibility for violence between those who obey orders and those who act on their own free will. In this case st. Augustine gave a clear explanation:

${ }^{40}$ Yurkevich P. D. (1860). Mir s blizhnim kak usloviye khristianskogo obshchyezhytiya. P. 76. (in Russian).

${ }^{41}$ Harris I. (2006). Peace Studies between the Two Infinities. Newsletters of the Concerned Philosophers for Peace, vol. 26 (2). Retrieved from: http://peacephilosophy.org/94/peace-studiesbetween-infinities-by-ian-harris (accessed 18 January 2020). 
A soldier, who kills the enemy is acting as an agent of the law, so he can easily perform his duty without inordinate desire (libibo). Furthermore, the law itself, which was established with a view to protecting the people, cannot be accused of any inordinate desire... [But as for someone who defends his own life, for example against a highway robber], I do not see how they can be excused, even if the law itself is just. For the law does not force them to kill; it merely leaves that in their power. They are free not to kill anyone for those things which can be lost against their will, and which they should therefore not love [i. e. their earthly life ${ }^{42}$.

This logic also implies a clear subsidiarity of responsibility between simple executors of orders (laws) and those who orders (or makes laws). So, a soldier, who does his duty on the battlefield even kills an enemy, is a hero, opposite, a politician, whose actions led to war and who orders to kill, is a criminal. The Nazis' atrocities were recognized as crimes by the Nuremberg Tribunal and their organizers were executed, but the destruction of Dresden, Hiroshima and Nagasaki as a result of massive or nuclear bombings lays as indelible spot of moral disgrace on the conscience of British and American politicians, though they did not violate the law. And if the positive results of peacebuilding are largely driven by the victory of each person over evil within oneself, then it applies to those who are endowed with power to a greater extent. John Chrysostom stated:

Truly the king is the one who conquers anger, and envy, and voluptuousness, submits all to the laws of God, keeps his mind free and does not allow the passion for pleasure to prevail over the soul. He would rule over people easily according to divine laws, so that he would be instead of a father for his subordinates, treating cities with all meekness ${ }^{43}$.

In the same time, Gregory the Theologian warned:

Otherwise, the greater evil will happen, than more a large number of people he will rule over, because the vice that spreads in many is more significant than the vice that dwells on one ${ }^{44}$.

${ }^{42}$ Augustine, st. (1993). On Free Choice of the Will. Ed. and trans. by T. Williams. Indianoapolis: Hackett. P. 25.

${ }^{43}$ John Chrysostom, st. (1898). Sravnenie vlasti, bogatstva i preimushchestv tsarskikh s istinnym i khristianskim lyubomudriem monasheskoy zhizni [The Comparison of the King's Power, Wealth and Advantages with the True and Christian Philisophy of Monastic Life]. Polnoie sobranie tvoreniy svyatitielya Ioanna Zlatousta [Complete collection of the works of St. John Chrysostom]. Vol. 1, Book 1. Sankt-Petersburg: Sankt-Pet. Theological Academy. Pp. 125, 129. (in Russian).

${ }^{44}$ Gregory the Theologian, st. (1912). Slovo 3 [Word 3]. Tvoreniya izhe vo svyatykh ottsa nashego Grigoriya Bogoslova, Arkhiepiskopa Konstantinopolskogo [The Works of Our Holy Father Gregory the Theologian, Archbishop of Constantinople], vol. 1. Sankt-Peterburg: Petr Soykin Publ. Pp. 518-519. (in Russian). 
The Ukrainian realities demand that truly peaceful people in the Christian sense of this definition, for whom peace is not only a political slogan, but the main internal unconditional and indispensable spiritual need, should be involved into the governance at all levels and in all regions.

\subsection{Value Dialogue: How Peace is Build}

In the process of peacebuilding, peace is not only a goal, but also a unifying value, and all other values, including religious, national or class identities, must to step back to it. Those social actors who advocate other priorities - such as past and present crusaders or jihadists, communists or Nazis - objectively serve the war. It is important to emphasize that the value priorities of Ukrainians are completely in line with the Christian axiological series, which was described above. According to a sociological poll conducted by the Gorshenin Institute in cooperation with the Friedrich Ebert Foundation, "peace" is the highest value for Ukrainian citizens (56.6\% of respondents), next come "value of human life" $(42.7 \%)$ and "human rights" $(33.3 \%)^{45}$. Obviously, that peacebuilding dialogue should be developed around these values exactly. Because, as Kostyrev argues, "shared values determine the potential for communication, in other words, the more commonality between the subjects, the faster they will reach understanding and the deeper it will be. The effect of trust as a necessary condition for social interaction arises in the process of communication exactly in the area of social actors' value frameworks' intersection" 46 .

The synergetics of the peacebuilding process is that, on the one side, the vision of peace as a common future, is the foundation of a peaceful dialogue, and, on the another side, this value dialogue opens up the prospect of a constructive transition from the chaos of war to the order of peace. As Fortman stresses, "the moral grounds for a conviction upon which responsible behaviour have to be constantly nurtured on the basis of a worldview shared by those concerned" ${ }^{47}$. Thus, we move to such a crucial component of peacebuilding praxeology as value communication. It should be emphasized that communication differs from other information processes because it aims to reach a certain community, that determines its peacebuilding potential. For

45 Internet-portal Dyvys' [Look]. 2017, 26 Oct. (in Ukrainian). Retrieved from: https://dyvys.info/2017/10/26/najbilshoyu-tsinnistyu-dlya-ukrayintsiv-ye-myr-najmenshoyupovaga-do-inshyh-kultur/ (accessed 20 January 2020).

${ }^{46}$ Kostyrev A. G. (2013). Ukraina: bufer ili forum? Mezhtsivilizatsionnaya kommunikatsiya kak geopoliticheskaya funktsiya Ukrainyi [Ukraine: buffer or forum? Inter-civilization communication as a geopolitical function of Ukraine]. LAP Lambert Academic Pablishing. ISBN 978-3-659-38256-7. P. 12.

${ }^{47}$ Fortman B. (2011) Religion and Human Rights: A Dialectical Relationship 
Christians, the foundation of such communion is unity in the Church of Christ through the sacrament of communion. From here it is clear that the Christian dimension of communication has profound content. It is expressed in the commandment: "Love the Lord your God with all your heart, and with all your soul, and with all your mind, and with all your strength" (Mk. 12:30, Mt. 22:37). Frank pointed to this meaning of Christian communication precisely, when he stated:

Service to God, carried out consciously or unconsciously, by hearsay, tradition and habit, is actually the basis of the whole social life of a person, outside of which it is generally unthinkable: it is expressed in the idea of a moral obligation that both the individual and society have equally ${ }^{48}$.

Yurkevich also relied on Christian values, considering the problem of communication as a means of achieving harmony in society:

A heart as bodily, soul and spiritual essence of human seeks good, fraternal communication. In this moral state, human destroys the sharp distance between himself and his neighbor, respects human dignity in all persons, respects others' rights and performs their duties, becomes able to sacrifice, forgive and cover others' weaknesses by love in the name of Christ $^{49}$.

Therefore, the communicative component of peacebuilding, which exists in the form of open discussion, along with impartial thought and critical thinking, presupposes the priority of higher spiritual values.

An example of such communication is the inter-denominational Christian ecumenical dialogue, which discusses the world's pressing problems of peace. The content of this communication is determined by a common value platform built on the three pillars of the Gospel - a love, charity and respect for the dignity of each person as God's creation. No wonder communication between Orthodoxy and Catholicism is called the dialogue of charity. This example serves as an guide to overcome all kind of hostility and, as a result, the cessation of wars and the victory over terrorism. In addition to its own example of humility and virtue, Church leaders and Christian volunteers are actively involved in helping the victims of armed conflicts, as well as helping to establish peaceful negotiations between the antagonistic parties. At the present stage, the situation in the Middle East, first of all in Syria, the armed

\footnotetext{
${ }^{48}$ Frank S. L. (1925). Religioznyie osnovy obshchestvennosti [Religious Foundations of the Public]. P. 24. (in Russian).

${ }^{49}$ Yurkevich P. D. (1990). Serdtze I yego znacheniye n duhovnoy zhyzni chelovyeka, po ucheniyu Slova Bozhiya. Philosophskiye proizvyedyeniya. (A heart and its meaning in the spiritual life of man, according to the teaching of the Word of God. Philosophical works. Moscow: Znaniye, pp. 226-227. (in Russian).
} 
conflict that breaks Ukraine and counterterrorism are the main subjects of the negotiations.

At the same time, it is important to emphasize that, although the surge of jihadism and the revitalization of ISIL have emerged as the main motivating factor for intensifying the dialogue between Orthodox, Catholics and Protestants, Christians do not regard Muslims as enemies, but rather seek for co-operation with Islam. For example, in a joint statement by Pope Francis and His Holiness Patriarch Cyril:

The serious problems facing the world today require the solidarity of all goodwill. Thus, we also recognize the importance of continuing a constructive dialogue with Islam based on mutual respect and friendship. Inspired by shared values and strengthened by genuine brotherly feelings, Muslims and Christians are called to cooperate for the sake of justice, peace, and respect for the dignity and rights of each person ${ }^{50}$.

Paying tribute to the bloody problems of the Middle East, it should be emphasized that it is of utmost importance for us to pay attention to how the high clergy of the Christian world propose to put an end to the war in Ukraine. The Ecumenical Patriarch Bartholomew and Pope Francis clearly defined the essence of the Christian approach to peace building in Ukraine:

We also remember all the people who experience the sufferings of war. In particular, we pray for peace in Ukraine, a country of ancient Christian tradition, while we call upon all parties involved to pursue the path of dialogue and of respect for international law in order to bring an end to the conflict and allow all Ukrainians to live in harmony ${ }^{51}$.

Therefore, in accordance with the principles of the Christian peacebuilding philosophy, establishing a broad public dialogue in Ukraine around such values as human right to life, human dignity and justice are the defining conditions for peace. And not only now along the line of collision and in the Donbass after its reintegration, but also all over Ukraine, understanding peacebuilding as an achievement of social harmony. As the All-Ukrainian Council of Churches and Religious Organizations notes:

All society and every citizen, whether politician or religious figure or media representative, should foster public peace and harmony, avoid hostility in their statements, seek ways of reconciliation through dialogue and mutual

${ }^{50}$ Sovmestnoe zayavlenie Papyi Rimskogo Frantsiska i Svyateyshego Patriarha Kirilla [Joint statement by Pope Francis and His Holiness Patriarch Cyril]. Habana, 13 Feb. 2016. (in Russian). Retrieved from: http://www.patriarchia.ru/db/text/4372074.html (accessed 22 January 2020).

${ }^{51}$ Ecumenical Patriarch Bartholomew and Pope Francis Sign Joint Declaration. Istanbul, 30 Nov. 2014. Retrieved from: https://www.patriarchate.org/-/ecumenical-patriarch-bartholomewand-pope-francis-sign-joint-declaration?inheritRedirect=true (accessed 22 January 2020). 
forgiveness. We ask that Ukrainian society be more tolerant. more compassionate and just to all its citizens without exception ${ }^{52}$.

The practical value of this work is contained in the possibility of using principal approaches and methods of the dialogue of charity to overcome armed violence, religious and nationalist extremism and to reconcile the warring parties. This task is especially urgent for the Ukrainian society.

\section{CONCLUSIONS}

The military-political, socio-economic, and international legal concepts could not create a reliable theoretical foundation for ensuring sustainable peace, because they overlook the role of human as a moral being in the process of peacebuilding. In modern conditions, when this role is growing rapidly, the appeal to the spiritual foundations of peacebuilding, which were developed within the framework of Christian philosophy, is productive.

The peacebuilding is an essential core of Christianity. From the ontological and axiological positions of the Christian peacebuilding philosophy, a war cannot be justified, a war cannot be a dignity deed, a war cannot be fair. Peacebuilding has universal value, only it is a truly dignity and just destination of human and society as a whole. Christian philosophy, defending the supremacy of spiritual factors over material as a condition of moral and social exaltation of human, regards the Gospel commandments as an invariable foundation of peacebuilding. Christian thinkers have shown that peacebuilding is the highest virtue as a manifestation of love and charity.

They consider peacebuilding primarily as humanbuilding, and argue that conflicts, strife, crimes and wars with their tragic consequences are external symptoms of sin as a spiritual illness. So, Christians believe that only spiritual perfection can eliminate not only the external symptoms of this disease, but also the disease itself and to return human to God. Based on the Christian peacebuilding philosophy, we can conclude that to prevent evil through violence means to prevent sin, but to take revenge by violence for evil means to commit sin.

All conditions of peacefully co-existence are based on values that create by Christian philosophy: non-violence is based on the human right to life, autonomy - on the human dignity, awareness - on the understanding of justice as love and charity, and communication - on the openness to peaceful value dialogue.

${ }^{52}$ Zvernennia Vseukrainskoi Rady Tserkov I Relihiinykh Orhanizatsii Shchodo Utverdzhennia Myru Ta Postupu Ukrainskoho Suspilstva [The All-Ukrainian Council of Churches and Religious Organizations Appeal on Promoting Peace and the Progress of Ukrainian Society]. Kramatorsk, 02 Nov. 2016. (in Ukrainian). Retrieved from: http://vrciro.org.ua/ua/statements/ 475-uccrostatement-on-peace-in-ukraine (accessed 22 January 2020). 
The content of Christian philosophy - the right to life and respect for the dignity of every human being as the creation of God, justice as a derivative of love and charity, equality, solidarity, non-discrimination and dialogue - is the spiritual foundation of UN principles of peace co-existence and determines the humanistic orientation of international law for peacebuilding. These principles are crucial for a philosophical understanding of the prospects of Ukraine's exit from the current acute socio-political crisis.

\section{SUMMARY}

The article deals ontological, anthropological, axiological and praxeological measurements of Christian peacebuilding philosophy. The author critically analyzes the content of the military-political, socio-economic and international legal concepts of ensuring peace and concludes that they could not create a reliable theoretical foundation for ensuring sustainable peace. He demonstrates that Christian philosophy represents the peace as a basic category of being and as an all-embracing complex value. Herewith, the right to life is the ontological basis of peacebuilding. Human dignity as a spiritual basis of peacebuilding philosophy logically derives from the faith in Christ the Savior. The author insists that an interpretation of justice as charity and forgiveness is an axiological core of Christian peacebuilding philosophy and gives the Christian philosophers' arguments that show love as the anthropological essence of peacebuilding. Paper accents that accordingly to the Christian peacebuilding philosophy only victory over evil in one's soul opens the possibility for a person to use force adequately. The author argues that the Christian approach to peacebuilding implies the development of a value dialogue between social actors, and cites as an example the Christian dialogue of charity as a response to the challenges of wars and terrorism.

\section{REFERENCES}

1. Augustine, st. (1943). Answer to Sceptics. Ed. by R/ Arbesman. Trans. D. J. Kavanagh. New York: Oxford University Press.

2. Augustine, st. (1993). On Free Choice of the Will. Ed. and trans. by T. Williams. Indianoapolis: Hackett.

3. Bacon F. (2014). Introductory dedication of "An Advertisement Touching a Holy War" to Bishop Lancelot Andrews. The Essays and Counsels, Civil and Morales. B\&R Samizdat Express. Pp. 351-362.

4. Bacon F. (2014). Of Atheism. The Essays and Counsels, Civil and Morales. B\&R Samizdat Express. Pp. 225-248.

5. Barenboym P. D. (2016). Bybleyskiy moment philosophiyi prava [Biblical moment of the philosophy of law]. Mediaglagol. Pravoslavnyi obrazovatel'nyi portal [Mediaglagol. Ortodox educational portal]. 
(in Russian). Retrieved from: http://mediaglagol.com.ua/book/bibleyiskiyi_ moment_filosofii_prava_pd_barenboyim. (accessed 15 January 2020).

6. Basil the Great, st. (2008). Beseda 9. O tom, chto Bog nie vinovnik zla [Conversation 9, That God is not the culprit of evil. Works, Vol. 1. Moscow: Blagovest. (in Russian).

7. Ecumenical Patriarch Bartholomew and Pope Francis Sign Joint Declaration. Istanbul, 30 Nov. 2014. Retrieved from: https://www.patriarchate.org/-/ecumenical-patriarch-bartholomew-and-popefrancis-sign-joint-declaration?inheritRedirect=true (accessed 22 January 2020).

8. Fortman B. (2011) Religion and Human Rights: A Dialectical Relationship. e-International Relations. 05 Dec. Retrieved from: http://www.e-ir.info/2011/12/05/religion-and-human-rights-a-dialecticalrelationship/ (accessed 14 January 2020).

9. Frank S. L. (1925). Religioznyie osnovy obshchestvennosti [Religious Foundations of the Public]. Put' [The Way], no. 1, pp. 11-25. (in Russian).

10. Galtung J. (1990). Cultural Violence. Journal of Peace Research, vol. 27, iss. 3, pp. 291-305. doi:10.1177/0022343390027003005.

11. Galtung J. (2011). Peace, Positive and Negative.The Encyclopedia of Peace Psychology, American Cancer Society, pp. 23-54. doi: $10.1002 / 9780470672532$.

12. Gittings J. (2015). Philosophy and Peace. The Question of Peace in Modern Political Thought, ed. by T. Koivukoski \& D. E. Tabachnick. Waterloo: Wilfred Laurier University Press, pp. 31-55.

13. Gregory of Nyssa, st. (1863). O blazhenstvah. Slovo 7 [About bliss. Word 7]. Complete set of Works. Mosow: V. Gotie's typography. Pp. 12-28. (in Russian).

14. Gregory the Theologian, st. (1912). Chudiesnyie pesnopieniia. Slovo 4, o mirie [The mysterious chants. Word 4, about the Peace. Tvoreniya izhe vo svyatykh ottsa nashego Grigoriya Bogoslova, Arkhiepiskopa Konstantinopolskogo [The Works of Our Holy Father Gregory the Theologian, Archbishop of Constantinople]. vol. 1. Sankt-Peterburg: Petr Soykin Publ. Pp. 20-29. (in Russian).

15. Gregory the Theologian, st. (1912). Slovo 3 [Word 3]. Tvoreniya izhe vo svyatykh ottsa nashego Grigoriya Bogoslova, Arkhiepiskopa Konstantinopolskogo [The Works of Our Holy Father Gregory the Theologian, Archbishop of Constantinople], vol. 1. Sankt-Peterburg: Petr Soykin Publ. Pp. 515-524. (in Russian).

16. Gregory the Theologian, st. (1912). Slovo 6, O mirie, skzannoie v prisutstvii ottza poslie priedydushchiego molchaniia po sluchaiu vossoiedinieniia monahov [Word 6, About the Peace, was said in the presence 
of the father after the previous silence, on the occasion of the reunion of monks]. Tvoreniya izhe vo svyatykh ottsa nashego Grigoriya Bogoslova, Arkhiepiskopa Konstantinopolskogo [The Works of Our Holy Father Gregory the Theologian, Archbishop of Constantinople]. vol. 1. Sankt-Peterburg: Petr Soykin Publ. Pp. 323-334. (in Russian).

17. Hamblet W. (2017). Harvesting the Human: Force and Persuasion in Human Societies. Concerned Philosophers for Peace Newsletter Online. Retrieved from: http://peacephilosophy.org/325/wendy-hamblet-harvestingthe-human-force-and-persuasion-in-human-societies (accessed 12 January 2020).

18. Harari Y. N. (2016). Homo Deus: A Brief History of Tomorrow. London: Harvill Secker.

19. Harris I. (2006). Peace Studies between the Two Infinities. Newsletters of the Concerned Philosophers for Peace, vol. 26 (2). Retrieved from: http://peacephilosophy.org/94/peace-studies-between-infinities-by-ian-harris (accessed 18 January 2020).

20. Ilyin I. A. (1995). O soprotivlenii zlu siloiu [About resistance to evil by force]. Collected Works in 10 vol. Vol. 5. Moscow: Russkaia kniga. p. 217. (in Russian).

21. Internet-portal Dyvys' [Look]. 2017, 26 Oct. (in Ukrainian). Retrieved from: https://dyvys.info/2017/10/26/najbilshoyu-tsinnistyu-dlya-ukrayintsivye-myr-najmenshoyu-povaga-do-inshyh-kultur/ (accessed 20 January 2020).

22. John Chrysostom, st. (1898). Sravnenie vlasti, bogatstva i preimushchestv tsarskikh $\mathrm{s}$ istinnym $\mathrm{i}$ khristianskim lyubomudriem monasheskoy zhizni [The Comparison of the King's Power, Wealth and Advantages with the True and Christian Philisophy of Monastic Life]. Polnoie sobranie tvoreniy svyatitielya Ioanna Zlatousta [Complete collection of the works of St. John Chrysostom]. Vol. 1, Book 1. Sankt-Petersburg: Sankt-Pet. Theological Academy. Pp. 120-131. (in Russian).

23. John Paul II (1991). Encyclical Centesimus annus. Ukrainian Catholic University: Institute of Religion and Society. (in Ukrainian). Retrieved from: http://irs.ucu.edu.ua/dzherela/sotsialni-entsikliki/ivan-pavlo-ii-centesimusannus-1991. (accessed 20 January 2020).

24. Kant I. (1993). Grounding for the Metaphysics of Morals. Trans. by J. W. Ellington, (3rd ed.). Indianoapolis: Hackett.

25. Kapto A. S. (1990). Filosofiya mira: istoki, tendentsii, perspektivyi [The Philosophy of Peace: Sources, Trends, Prospects]. Moscow: Politizdat. (in Russian).

26. Koshin V. (1990). Filosofiya mira v yadernyiy vek [The philosophy of peace in the nuclear age]. Voprosyi filosofii [The Questions of Philosophy], no. 5, pp. 39-54. (in Russian). 
27. Kostyrev A. (2013). Kommunikatsionnaya vlast: sotsialnyie seti kak instrumentyi noopolitiki [Communication power: social networks as tools of noopolitics]. Political design in the space of social communications, vol. 2, pp. 49-56. (in Russian).

28. Kostyrev A. G. (2013). Ukraina: bufer ili forum? Mezhtsivilizatsionnaya kommunikatsiya kak geopoliticheskaya funktsiya Ukrainyi [Ukraine: buffer or forum? Inter-civilization communication as a geopolitical function of Ukraine]. LAP Lambert Academic Pablishing.

29. Ksenofontov V. N. (2008). Mir kak sostoyanie obschestva [Peace as a state of society]. Moscow: Russian Academy of Public Administration. (in Russian).

30. Missiya Pravoslavnoi Tcerkvi v sovremennom mire [Orthodox Church's mission in the modern world]. (2016). VI Vsemirnyi Pravoslavnyi Sobor [VI World Orthodox Meeting], Shambezy, 26-28 Jan. 2016. (in Russian). Retrieved from: http://www.patriarchia.ru/db/print/4360988.html (accessed 18 January 2020).

31. Osnovy sotcialnoyi kontceptciyi Rus'koyi Pravoslavnoyi Tcerkvy [The Fundamentals of the Russian Orthodox Church's Social Concept] (2002). Kyiv: Information and Publishing Center of the Ukrainian Orthodox Church. (in Ukranian). Retrieved from http://www.patriarchia.ru/ua/db/text/ 1207692.html (accessed 16 January 2020).

32. Rynne T. J. (2008). Gandhi and Jesus: The Saving Power of Nonviolence. London: Orbis Books.

33. Sovmestnoe zayavlenie Papyi Rimskogo Frantsiska i Svyateyshego Patriarha Kirilla [Joint statement by Pope Francis and His Holiness Patriarch Cyril]. Habana, 13 Feb. 2016. (in Russian). Retrieved from: http://www.patriarchia.ru/db/text/4372074.html (accessed 22 January 2020).

34. Thomas Aquinas, st. (2010). O spravedlivosti, vopros 91. Summa teologiyi [About a Justice, question 58. Summa Theologiae]: in 12 vol. Ed. by S. I. Yeremeyev. Kyiv: Nika-Centre, vol. VI. (in Russian). Retrieved from: https://azbyka.ru/otechnik/konfessii/summa-teologii-tom-6/ (accessed 19 January 2020).

35. Traer R. (2009). Christian Support for Human Rights. Religion and Human Rights. Retrieved from: http://religionhumanrights.com/Religion/ Christian/christian.fhr.htm (accessed 14 January 2020).

36. Tuck R. (1999). The Right of War and Peace: Political Thought and the International Order from Grotius to Kant. New York: Oxford University Press.

37. What is Peacebuilding? (2018). Alliance for Peacebuilding. Retrieved from: https://allianceforpeacebuilding.org/what-is-peacebuilding/ (accessed 10 January 2020). 
38. Yurkevich P. D. (1860). Mir s blizhnim kak usloviye khristianskogo obshchyezhytiya (Trudy Kyivskoy Duhovnoy Academiyi) [Peace with the neighbor as a condition of a Christian cohabitation (The Works of the Kyiv Theological Academy)]. Philosophskiye proizvyedyeniya [The Philosophical Works]. Moscow: Znaniye, 1990. (in Russian).

39. Yurkevich P. D. (1990). Serdtze I yego znacheniye n duhovnoy zhyzni chelovyeka, po ucheniyu Slova Bozhiya. Philosophskiye proizvyedyeniya. (A heart and its meaning in the spiritual life of man, according to the teaching of the Word of God. Philosophical works. Moscow: Znaniye, pp. 226-227. (in Russian).

40.Zvernennya Vseukrayinskoyi Rady Cerkov i Religijnykh Organizacii shhodo Stanovlennya Spravedlyvosti v Ukrayini [The Statement of the All-Ukrainian Council of Churches and Religious Organizations on the establishment of justice in Ukraine]. Kyiv, 17 May 2016. (in Ukrainian). Retrieved from: http://vrciro.org.ua/ua/statements/465-uccrostatement-justicecourt-judge-ukraine (accessed 16 January 2020).

41.Zvernennia Vseukrainskoi Rady Tserkov i Relihiinykh Orhanizatsii shchodo Utverdzhennia Myru Ta Postupu Ukrainskoho Suspilstva [The AllUkrainian Council of Churches and Religious Organizations Appeal on Promoting Peace and the Progress of Ukrainian Society]. Kramatorsk, 02 Nov. 2016. (in Ukrainian). Retrieved from: http://vrciro.org.ua/ua/ statements/475-uccrostatement-on-peace-in-ukraine (accessed 22 January 2020).

\section{Information about the author: Nikolay Nesprava,} $\mathrm{PhD}$ in Philosophical Sciences, Docent, Associate Professor at the Department of Social and Humanitarian Disciplines, Dnipropetrovsk State University of Internal Affairs 26, Prospect Gagarina, Dnipro, 49000, Ukraine ORCID ID: http://orcid.org/0000-0003-0415-1837 